\title{
Genetic aspects of tuberous sclerosis in the west o Scotland
}

J R SAMPSON*, S J SCAHILL*, J B P STEPHENSON $\dagger$, L MANN*, AND

J M CONNOR*

From * the University Department of Medical Genetics, Duncan Guthrie Institute of Medical Genetics $\overrightarrow{\vec{c}}$ Yorkhill, Glasgow G3 8SJ; and †Fraser of Allander Assessment Unit, Royal Hospital for Sick Children Yorkhill, Glasgow.

SUMMARY Complete ascertainment of tuberous sclerosis was attempted in the west of Scotlandु (population 2763000 ). A total of 101 patients was identified, giving an overall minimurip prevalence of 1 in 27000 , but for children under 10 years of age the minimum prevalence was 1 in 12000 . Both parents of 84 of the ascertained cases were assessed for signs of tuberous sclerosis. In 51 pairs of parents no evidence of the condition was seen, indicating that up to $60 \%$ of th: cases were new mutations. The mutation rate was estimated at $2.5 \times 10^{-5}$ mutations per gene pew generation. Analysis of parental ages for the new mutations did not show a significant age effect. Thirty-five patients occurred in 13 families containing other affected subjects. The pattern of inheritance was consistent with an autosomal dominant trait in these families. In one sibship? non-penetrance or gonadal mosaicism resulted in affected sibs with normal parents. Of twQ further sibships where non-penetrance was suspected, one was shown to represent a single net mutation in monozygotic twins and the other to involve non-paternity.

Tuberous sclerosis (TS) is an accepted autosomal dominant trait with characteristic dermatological and neurological features (table 1). Mental handicap occurs in more than half of recognised affected subjects. ${ }^{1}$ The variable expression seen in TS can often complicate initial diagnosis; this, however, is facilitated by adherence to diagnostic criteria as described by Gomez. ${ }^{2}$ In recent years the recognition of more diagnostic signs together with more complete evaluation of family members has led to increasing estimates of the prevalence of TS. ${ }^{1}$ The occasional inability to detect any diagnostic features in obligate carriers of the TS gene has led to reports of non-penetrance or gonadal mosaicism ${ }^{3-5}$ with implications for genetic counselling of the families of apparently sporadic cases. The present study aimed to determine the prevalence and to investigate the main genetic aspects of tuberous sclerosis in the west of Scotland.

Patients, methods, and results

A S CERTAINMENT

TS patients were ascertained from the records of the
West of Scotland Regional Genetic Service, the Fraser of Allander Assessment Unit (paediatric neurology), and the Tuberous Sclerosis Association

Consultants in paediatrics, neurology, dermas tology, and mental handicap in the region (approxi mately 100 ) were approached by questionnaire ig order to maximise ascertainment and all responded Of the 101 cases identified, 97 were seen by one of more of the authors; the other seven had bee diagnosed by other hospital specialists. The diagnoso tic criteria of Gomez $^{2}$ (table 1) were fulfilled by aif

TABLE 1 Diagnostic criteria for tuberous sclerosis (aftex Gomez ${ }^{2}$ ).

\begin{tabular}{|c|c|}
\hline $\begin{array}{l}\text { Primary criteria } \\
\text { (only one required } \\
\text { for diagnosis) }\end{array}$ & $\begin{array}{l}\text { Secondary criteria } \\
\text { (two required for } \\
\text { diagnosis) }\end{array}$ \\
\hline $\begin{array}{l}\text { Adenoma sebaceum } \\
\text { Ungual fibromas } \\
\text { Cortical tuber } \\
\text { Subependymal hamartomas } \\
\text { Multiple retinal hamartomas } \\
\text { Fibrous forehead plaque }\end{array}$ & $\begin{array}{l}\text { Infantile spasms } \\
\text { Hypopigmented macules } \\
\text { Shagreen patch } \\
\text { Single retinal hamartoma } \\
\text { Bilateral renal cysts or } \\
\quad \text { angiomyolipomata } \\
\text { Cardiac rhabdomyoma(ta) } \\
\text { First degree relative with TS }\end{array}$ \\
\hline
\end{tabular}


patients in the study. Where possible both parents (and usually sibs) were assessed for signs of TS.

\section{PREVALENCE}

A total of 101 cases, 52 male and 49 female, was identified living in the west of Scotland, population $2763000,{ }^{6}$ on the study date of 1 June 1986 . The overall prevalence of ascertained cases was 1 in 27000 and in the population under 10 years 1 in 12000 . The birth frequency is predicted to be higher than the latter figure as mildly affected subjects will often not be diagnosed during childhood.

\section{IN HE R IT A N C E}

Both parents of 84 of the 101 patients in the study were clinically assessed for signs of TS (this included fundoscopy and Wood's light examination of the skin). In the remainder, assessment was not possible owing to the death of one or both parents or separation with one being untraceable. In two families the affected children had been adopted. In 51 of the 84 cases there was no evidence of TS in either parent. Thus, the proportion of sporadic cases in this group was $60 \%$. If all those cases in which examination of both parents was not possible represented new mutations, the overall proportion of new mutations could be as high as $70 \%$.

Thirty-five patients were members of families with more than one affected subject. In one family four generations were affected, in four families three generations, and in seven families two generations. In these families TS was inherited as an autosomal dominant trait and no skipped generations were seen. Great variation in expression was evident within as well as between families. Subgrouping of clinical features among these families, which might suggest heterogeneity, was not noted.

A set of affected twins with normal parents (Glasgow pedigree 4521) have previously been reported as dizygotic on the basis of serum alanine aminotransferase phenotypes. ${ }^{7}$ DNA fingerprinting, however, showed them to be monozygotic and to represent a single new mutation. In a second pedigree, previously considered to illustrate nonpenetrance (Glasgow pedigree $3421^{5}$ ), the $\alpha$ globin $3^{\prime}$ hypervariable probe was used to show nonpaternity. Inheritance from the biological father could not be confirmed as he was not available for clinical assessment. The parents of a further pair of affected sibs (Glasgow pedigree 4151) were assessed clinically (including Wood's light and fundoscopy), by brain CT scan and renal ultrasound, all with normal results. Paternity was confirmed using the $\alpha$ globin $3^{\prime}$ hypervariable probe. This was the only pedigree in which an obligate gene carrier did not fulfil the diagnostic criteria of Gomez. ${ }^{2}$

\section{PARENTAL AGE EFFECT}

For sporadic cases the mean paternal age of 30.02 years (SD 6.6) and mean maternal age 27.2 years (SD 5.7) did not differ significantly from those in the Scottish population (paternal 30.8 years, SD 7.07; maternal 27.2 years, SD 6.23 , calculated from the Report of the Registrar General for Scotland 1969) ( $>0 \cdot 1$, Student's $t$ test).

\section{MUTATION RATE}

Assuming complete penetrance, a birth frequency of 1 in 12000 , and the proportion of new mutations to be at least $60 \%$, a minimum estimate of the mutation rate is $2.5 \times 10^{-5}$ mutations per gene per generation.

\section{Discussion}

The overall prevalence of tuberous sclerosis found in this study was 1 in 27000 , slightly higher than previous estimates based on large numbers of cases (table 2). Early population surveys greatly underestimated the prevalence of TS. ${ }^{8-11}$ Other authors

TABLE 2 Tuberous sclerosis: previous genetic studies.

\begin{tabular}{|c|c|c|c|c|c|}
\hline Authors & Reference & Cases & $\begin{array}{l}\text { Estimated } \\
\text { prevalence }\end{array}$ & $\begin{array}{l}\text { Proportion of } \\
\text { sporadic cases }\end{array}$ & $\begin{array}{l}\text { Mutation } \\
\text { rate } \\
\left(\times 10^{-5}\right)\end{array}$ \\
\hline $\begin{array}{l}\text { Gunther and Penrose } \\
\text { Borberg } \\
\text { Stevenson and Fisher } \\
\text { Nevin and Pearce } \\
\text { Zaremba } \\
\text { Bundey and Evans } \\
\text { Singer } \\
\text { Donegani et al } \\
\text { Fleury et al } \\
\text { Hunt and Lindenbaum } \\
\text { Wiederholt et al } \\
\text { Present study }\end{array}$ & $\begin{array}{r}12 \\
8 \\
9 \\
11 \\
13 \\
17 \\
10 \\
14 \\
16 \\
1 \\
15\end{array}$ & $\begin{array}{r}20 \\
37 \\
9 \\
18 \\
40 \\
71 \\
26 \\
6 \\
48 \\
68 \\
8 \\
104\end{array}$ & $\begin{array}{l}1 \text { in } 30000 \\
- \\
1 \text { in } 150000 \\
1 \text { in } 100000 \\
1 \text { in } 23000 \\
- \\
1 \text { in } 170000 \\
1 \text { in } 10000 \\
- \\
1 \text { in } 34000 \\
1 \text { in } 9400 \\
1 \text { in } 27000\end{array}$ & $\begin{array}{l}50 \% \\
57-79 \% \\
7 \text { of } 9 \\
66 \% \\
58 \% \\
86 \% \\
65 \% \\
- \\
56 \% \\
50-75 \% \\
6 \text { of } 8 \\
60 \%\end{array}$ & $\begin{array}{l}\frac{16}{-} \\
\overline{10} \cdot 5 \\
\frac{11}{6} \\
\frac{-}{25} \\
\frac{25}{25}\end{array}$ \\
\hline
\end{tabular}


studied subpopulations of institutionalised patients $^{1213}$ or based their estimates on very small numbers of cases. ${ }^{14} 15$ The recognition of further diagnostic signs and formulation of diagnostic criteria $^{2}$ has enabled better ascertainment in recent studies. ${ }^{116}$ Estimates of the prevalence of TS will inevitably be underestimates beause of the occurrence of minimally affected cases who may not come to medical attention. We often ascertained mildly affected subjects through more severely affected descendants. As in previous studies a much higher prevalence was found among children ( 1 in 12000 under 10 years) than among adults. This reflects in part the increased mortality associated with the condition and possibly increasing diagnostic awareness among paediatricians.

Because most large studies have not attempted thorough assessment of the parents of apparently sporadic cases, the proportion of new mutations is likely to have generally been overestimated. Although we attempted to examine the parents of index cases wherever this was possible, they were only rigorously investigated (brain CT scan, renal USS, skeletal survey) where further children were being considered, doubtful signs of TS were found, or if they were taking part in linkage studies. The proportion of sporadic cases among those whose parents were clinically evaluated is compared with previous reports in table 2 . The lack of a significant parental age effect for new mutations is in keeping with the findings of previous studies which have addressed this question. ${ }^{811} 17$ The mutation rate for the TS gene has most recently been estimated at $2.5 \times 10^{-5}$ per gene per generation. ${ }^{1}$ We derived the same figure from our data, which gave a higher prevalence but a lower proportion of fresh mutations. This mutation rate would suggest 18 new cases of TS per year to normal parents in the UK.

Among those families in which more than one person was affected, only one subject was thought to be a gene carrier not fulfilling Gomez's criteria. ${ }^{2}$ Affected sibs with normal parents, apparent gene carriers, are described elsewhere,$^{35}$ as is a pedigree in which affected cousins have normal parents. ${ }^{4}$ In other reported families presumed gene carriers have been incompletely investigated. ${ }^{18} 19$ Non-penetrance, gonadal mosaicism, genetic heterogeneity (recessive inheritance), and non-paternity might account for the observation of these unusual pedigrees. This has practical relevance and when counselling the normal parents of apparently sporadic cases we currently advise a recurrence risk of $1 \%$. Although ultrasound detection of fetal cardiac rhabdomyomata has enabled prenatal diagnosis of $\mathrm{TS},{ }^{21}$ its reliability is unknown.

Linkage between TS and the ABO blood group has been reported, ${ }^{22}$ suggesting that the TS locus (TSC) maps to the distal long arm of chromosome 9. A further study found linkage between a poly-o morphism at the c-abl locus, which maps to chromo-흘 some 9 band $\mathrm{q} 34$, and TS. ${ }^{23}$ Subsequently, early $\frac{\bar{s}}{\vec{p}}$ prenatal exclusion was reported in an extensive $\mathbb{\Omega}_{\Omega}^{\mathbb{D}}$ family showing linkage in that study. ${ }^{24}$ Recently, recombinations between $A B O$ and TSC have been noted $^{25.26}$ and the question of genetic heterogeneity? has been raised. In the families ascertained in the $\overrightarrow{-}$ present study there was no clinical evidence of heterogeneity, but further linkage studies are clearly required before prenatal DNA diagnosis can be more widely offered.

\section{References}

1 Hunt A, Lindenbaum RH. Tuberous sclerosis: a new estimate of prevalence within the Oxford region. J Med Genet 1984;21:C 272-7.

2 Gomez MR. Clinical experience at the Mayo Clinic. In: Gomez MR, ed. Tuberous sclerosis. New York: Raven Press, 1979:רి 11-26.

3 Wilson J, Carter CO. Genetics of tuberous sclerosis. Lancet $\overrightarrow{0}$ 1978;i:340.

4 Baraitser M, Patton MA. Reduced penetrance in tuberoussclerosis. J Med Genet 1985;22:29-31.

5 Connor JM, Stephenson JBP, Hadley MDM. Non-penetrance in tuberous sclerosis. Lancet 1986;ii:1275.

6 Annual report of the Registrar General for Scotland 1986. $\overline{\mathrm{D}}$ London: HMSO, 1986.

7 Primrose DA. Epiloia in twins: a problem in diagnosis and counselling. J Ment Defic Res 1975;19:195-203.

8 Borberg A. Clinical and genetic investigations into tuberous $\overline{\bar{O}}$ sclerosis and Recklinghausen's neurofibromatosis: contribution to elucidation of interrelationship and eugenics of syndromes. Acta Psychiatr Scand (suppl) 1951;71:11-239.

9 Stevenson AC, Fisher OD. Frequency of epiloia in NorthernIreland. Br J Prev Soc Med 1956;10:134-5.

10 Singer K. Genetic aspects of tuberous sclerosis in a Chinese population. Am J Hum Genet 1971;23:33-40.

11 Nevin NC, Pearce WG. Diagnostic and genetical aspects of

12 Guberous sclerosis. J Med Genet 1968;5:273-80. 413-30.

13 Zaremba J. Tuberous sclerosis: a clinical and genetical investiga음 tion. J Ment Defic Res 1968;12:63-80.

14 Donegani G, Gratarolla FR, Wildi E. Tuberous sclerosis. In Vinken PJ, Bruyn GW, eds. The phakomatoses. Handbook of clinical neurology. Vol 14. Amsterdam: North-Holland N 1972:340-89.

15 Wiederholt WC, Gomez MR, Kurland LT. Incidence and prevalence of tuberous sclerosis in Rochester, Minnesota, 195 仡
through 1982. Neurology (Minneap) 1985;35:600-3.

16 Fleury P, de Groot MP, Delleman JW, Verbeeten B Jro Frankenmolen-Witkiezwicz IM. Tuberous sclerosis: the incidence of sporadic versus familial cases. Brain Dev 1980;2 들

17 Bundey S, Evans K. Tuberous sclerosis: a genetic study. $\overbrace{}^{+}$ Neurol Neurosurg Psychiatry 1969;32:591-603.

18 Rushton AR, Shaywitz BA. Tuberous sclerosis: possible modo ification of the phenotype by an unlinked dominant gene. $J$ MedD Genet 1979;16:32-5.

19 Lowry RB, Dunn HG, Paris RP. Inheritance of tuberou

20 Crawford DC, Garrett C, Tynan M, Neville BG, Allan LD 
Cardiac rhabdomyomata as a marker for the antenatal detection of tuberous sclerosis. J Med Genet 1983;20:303-12.

21 Journel H, Roussey M, Milton J, Almange C, Le Marec B. Prenatal diagnosis of familial tuberous sclerosis following detection of cardiac rhabdomyoma by ultrasound. Prenat Diagn 1986;6:283-9.

22 Fryer AE, Connor JM, Povey S, et al. Evidence that the gene for tuberous sclerosis is on chromosome 9. Lancet 1987;i:659-61.

${ }^{23}$ Connor JM, Pirrit LA, Yates JRW, Fryer AE, Ferguson-Smith MA. Linkage of the tuberous sclerosis locus to a DNA polymorphism detected by v-abl. J Med Genet 1987;24:544-6.
24 Connor JM, Loughlin SAR, Whitle MJ. First trimester prenatal exclusion of tuberous sclerosis. Lancet 1987;i:1269.

25 Northrup H, Beaudet AL, O'Brien WE, Herman GE, Lewis RA, Pollack MS. Linkage of tuberous sclerosis to ABO blood group. Lancet 1987;ii:804-5.

26 Renwick JH. Tuberous sclerosis and ABO. Lancet 1987;ii: 1096-7.

Correspondence and requests for reprints to $\mathrm{Dr} J \mathrm{R}$ Sampson, Duncan Guthrie Institute of Medical Genetics, Yorkhill, Glasgow G3 8SJ. 